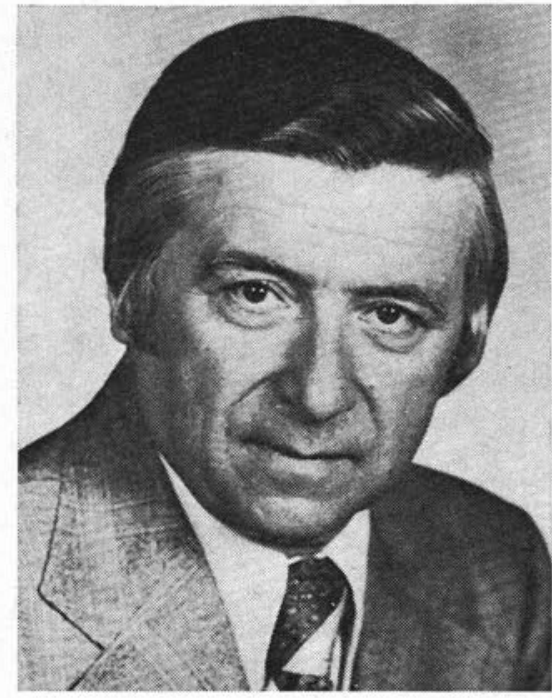

P. E. Boucher President

\section{President's Report}

The 1977 Annual Meeting, hosted in excellent style by the Vancouver Section, marked the end of a busy and eventful year for CIF/IFC members. It also produced indications of some of the challenges to be accepted in the coming year.

One can look back on the 1977 Annual Meeting with pride, warmth, and enthusiasm:

Pride: in belonging to an Association of dedicated people who while striving to better themselves and their profession, show deep and honest concerns for the improvement of forestry practices and forest management in our country.

Fier: de constater qu'une Section, par un travail d'ensemble de ses membres, qui demandait de longues heures et bien des sacrifices personnels, puisse nous offrir une réunion de si grand calibre. Nous nous devons d'offrir nos plus sincères félicitations au comité Hampco 77 de la Section de Vancouver.

Warmth: in meeting old friends, renewing acquaintances and making new friends. Throughout the meeting, even with our regional differences, there was a definite feeling of cooperation. After all, are we not bound by the same objective; the advancement of forestry in Canada?

Enthusiasm: the high degree of participation during the technical and business sessions as well as during the excellent social events showed the enthusiasm which was prevalent during the entire meeting.
The theme of this year's meeting - Canada's Forests - From Seed to Sale - was highly appropriate. The competent speakers and panelists were clear and emphatic in voicing their concerns, our concerns, regarding the need for intensive forest management in Canada. They left no doubts as to the consequences of a "laissezfaire" or "do-nothing" attitude from governments, industry and all who are closely connected with the forestry scene. In very plain words - all of us.

Les orateurs très connaissants laissaient aucun doute des problèmes sérieux, soit économiques ou socio-économiques, que l'on pourrait faire face dans un avenir assez rapproché si nos gouvernements et nos industries forestières n'agissent pas maintenant pour accentuer l'aménagement intensif de nos forêts.

The Honorable Tom Waterland, Minister of Forests for British Columbia, spoke quite forcefully at the B.C. luncheon, and I quote; "From now on, lip service, about intensive forestry will be finished in British Columbia. Hopefully, the rest of Canada will follow. Forestry is for real in this country, not just a side show, or we're in trouble".

Our Secretary Manager and I attended the successful Canadian Forestry Association - National Forest Regeneration Conference - held in Quebec City. Several CIF/IFC members actively participated in one capacity or another; National Team, co-chairmen, moderators, panelists, and section papers, etc. Dr. Gordon Weetman, on behalf of our association, presented one of the two national papers - "Forest Regeneration in Canada."

Que la conférence ait été un succès, il n'y a pas de doute. Nos sincères félicitations à Maurice Vézina, président de l'Association Forestière Canadienne, l'âme de la conférence, qui par son travail acharné et sa persévérance mena la conférence à sa réussite.

Le Docteur Rosaire M. Couturier dans sa conférence d'ouverture disait, et je cite: - "devant l'ampleur du problème de la régénération des forêts surtout dans l'Est du Canada, on peut dire que l'avenir, même à court terme, signifie beaucoup pour la crédibilité des forestiers et des aménagistes dans leur aptitude à préconiser les techniques d'aménagement intensif à la hauteur des problèmes de l'heure."

CIF/IFC members were pleased to have participated and pledge support for any future action. A subsequent Forestry Chronicle issue will carry details of the National Conference. 
Both meetings showed clearly that forest renewal is a major problem in Canada and will only be solved by hard work, commitment and cooperative action. I, for one, firmly believe things will and must happen now.

There is no doubt that the Pearse, Armson, and Reed studies and recommendations will have substantial impacts on forest policies in the near future. Tremendous challenges are just ahead for all of us; I'm sure we will accept these with great determination.

Your Executive Committee will be meeting shortly with government officials and will continue to voice your concerns. Strong resolutions from the Annual Meeting were quite clear and explicit that your concerns should be brought at all levels of government. At about the same time, our Research Priority Committee will be meeting with officials of the National Research Council to emphasize, now more than ever, the great need for continued and intensified research in forestry.

We will continue to support the development of a National Forest Policy being quite aware of regional differences. Surely, we can all work together in seeking the best methods and practices possible to tend the most important of our renewable resources - our forests.

Our past president in his final report says: Membership has been an ever-present cross to bear. The Executive Committee and the Directors have spent hours of serious discussions on the matter. One must realize that membership should be a priority with all the members; not just for a dedicated few.

The backbone of our Association is the sections. This is where the action is and must be. Several sections have produced outstanding programs involving members as well as the public. With hard work, commitment and goodwill there is no reason why others cannot be as successful; but, this means the support of all the members.

We are supposed to be dedicated to our profession and the science and art of forest man- agement. If this is really the case, in what better extra-vocational way can we show this dedication than by active membership in our Association.

Nous croyons au vieux dicton - l'union fait la force. J'ose croire que beaucoup plus de forestiers pourraient et devraient joindre notre association. Plus nombreux nous serons plus d'impacte nous aurons auprès de ceux qui établissent les politiques forestières. Qu'il existe des lacunes au sein de notre association, est peut-être vrai. Votre appui, votre participation, vos suggestions nous aiderons à améliorer la situation. Tous ensemble nous pouvons trouver un juste milieu.

Of a number of objectives I had set for the coming year, I wish to mention two at this time. The first, to try to convince our members of the necessity to communicate fully and honestly with the citizen in his "milieu" on all forestry matters. This could ensure a satisfied people and could be the most important safeguard for long term stability in forest policies. It is my intention to deal more fully with this matter in a subsequent issue of The Forestry Chronicle.

The second objective is for the members of the Executive Committee to visit as many sections as possible in the coming year. We need to know you and want you to know us. In the discussion of mutual concerns and problems. How can we of the Executive Committee best serve our membership. I have always believed in the eye-ball to eye-ball communication approach.

J'ai l'intention de visiter plusieurs de nos sections durant la prochaine année pour faire connaître d'avantage notre association. Nous pourrons discuter ensemble comment l'IFC peut améliorer ses services à ses membres.

In closing, it is evident that there is great interest in the proper development of our forests in Canada.

We are facing an exciting era in forestry and each and every one of us should want to share in this excitement. 